\title{
Dominant drivers of plant community assembly vary by soil type and time in reclaimed forests
}

\author{
Kaitlyn E. Trepanier (D) Bradley D. Pinno • Ruth C. Errington
}

Received: 30 June 2020/ Accepted: 29 October 2020/Published online: 5 December 2020

(C) The Author(s) 2020

\begin{abstract}
Information on plant community assembly mechanisms is limited on forest reclamation sites after mining in the Canadian boreal forest. We assessed the change in plant community composition after Year 2 and Year 5 on species-rich forest floor mineral mix (FFMM) and species-poor peat mineral mix (PMM) reclamation soils by examining assembly mechanisms, i.e., seed bank, seed rain, biotic dispersal, vegetative expansion, and competition. Initial plant cover and diversity were greater on FFMM due to nonnative species originating from the seed bank, which had $5 \times$ more seeds in the FFMM. By Year 5, both soil types had approximately $40 \%$ cover and 80 species richness due to the addition of wind and bioticdispersed species and were characterized by a shift towards native species. Native forbs using vegetative reproduction expanded up to $2 \mathrm{~m}$ from FFMM into PMM. At Year 5 competition does not seem to have a large role in the structuring of the vegetation community. Overall, multiple factors were involved in structuring plant communities on reclamation sites,
\end{abstract}

Communicated by Lesley Rigg.

K. E. Trepanier $(\bowtie) \cdot$ B. D. Pinno

University of Alberta, 442 Earth Science Building,

Edmonton, AB T6G 2E3, Canada

e-mail: ktrepani@ualberta.ca

R. C. Errington

Natural Resources Canada, Canadian Forest Service,

Edmonton, AB, Canada but we observed a general convergence between plant communities on different soil types in a relatively short period of time.

Keywords Plant community mechanisms .

Succession $\cdot$ Reclamation $\cdot$ Boreal

\section{Introduction}

Revealing the mechanisms underlying succession leads to a better understanding of plant community assembly (Cook et al. 2005). Plant community assembly deals with various mechanisms such as the arrival, establishment, and persistence of species present at any particular location and how they are related to the species pool within the region (Hobbs et al. 2014). To be able to predict future successional trajectories of ecosystems, we need a better understanding of how plant communities are establishing following disturbances.

The boreal region in Canada accounts for $28 \%$ of the country's forests and is a disturbance adapted ecosystem (Brandt et al. 2013). Plant community succession is strongly influenced by the type, severity, and frequency of the disturbance (Hart and Chen 2006; Macdonald and Fenniak 2007). Following a disturbance, vegetation re-establishes through buried seeds and propagules or arrival from surrounding areas 
(Roberts 2004; Rydgren et al. 1998). Oil sands mining represents a disturbance that exceeds the severity of natural disturbances in this region (Dhar et al. 2018). During oil sands mining the topsoil, subsoil, and overburden are removed and then placed on constructed landforms during subsequent reclamation. Therefore, plant community development on reclaimed land will likely differ from naturally disturbed sites (Dhar et al. 2018). The severe disturbance to the soil, along with the removal of understory vegetation and canopy provides a starting point to examine how communities form after the site is reset to the initial stages of secondary succession (Roberts 2004; Young et al. 2001). The complexity of the interactions that control plant communities reinforces our need to have field studies in a semi-controlled environment such as oil sands land reclamation sites. These sites can be manipulated through landform construction, soil placement, and soil type selection allowing for partial control of the environment and contrasting ecological conditions. Although our understanding of how plants are re-establishing using various assembly mechanisms following a severe anthropogenic disturbance is growing, the specific contribution of each of these factors in developing the aboveground community as a whole, over time, is still unknown.

There are two main cover soil types used in oil sands reclamation: forest floor mineral mix (FFMM) and peat mineral mix (PMM). FFMM is the combination of the organic forest floor layer and underlying mineral soil salvaged from upland forests (Alberta Environment and Water 2012). FFMM has greater nutrient availability and has higher species richness of plant propagules than other reclamation soils but is in limited supply (Macdonald et al. 2015). PMM is a mixture of lowland peat deposits and underlying mineral soil (Alberta Environment and Water 2012). PMM is a more common reclamation soil in the study region and is ideal for tree and woody species establishment due to its high organic matter, water holding capacity, and surface roughness (Mackenzie and Quideau 2012; Pinno and Hawkes 2015; Pinno and Errington 2015).

With large scale disturbances, the plant community is altered, and succession is reset, causing the regeneration of plants from the seed bank to be a large contributor in the developing aboveground community (Mackenzie and Naeth 2010). The seed bank is expected to play a dominant role in early composition, but the longer-term role is unknown. Salvaged cover soil is a significant resource for initially establishing vegetation communities following disturbance (Mackenzie and Naeth 2010) with FFMM known for providing a rich seed bank (Errington and Pinno 2015; McMillan et al. 2007). In contrast, the seed bank for lowland derived PMM contains mainly peatlandassociated species that are suited to hydric conditions; therefore, the species may not be suited to conditions on reclaimed upland sites (Macdonald et al. 2012, 2015).

After initial colonization, species establishment and expansion are driven in part by sexual (seed) and asexual reproduction (clonal fragments and vegetative expansion) (Corbin et al. 2016). Seed-based reproduction is generally more effective because of rapid colonization and widespread dispersal distance compared to vegetative expansion (Silvertown 2008). Incoming seed rain species in this region is generally from wind dispersing trees or early successional species that have a continual input of seed into an area (Corbin et al. 2016; Gallagher et al. 2011). Species using vegetative reproductive structures have a relatively slow rate of expansion which is one of the downfalls of this reproductive method (Jones and Landhäusser 2018; Robinson and Handel 2000). However, many of the early successional species that use wind or gravity dispersal are also rhizomatous, such as Sonchus sp., Chamerion sp., and Calamagrostis canadensis. Once species establish vegetative colonization may play a larger role in colonization in later stages of succession.

As disturbed ecosystems increase in complexity, seed dispersal through biotic (mainly birds and mammals) interactions become important for the development of late-successional fruiting and woody species (Rey Benayas et al. 2008; Corbin et al. 2016). Morphological adaptations of seeds, including the use of barbs, hooks, and colorful seed coats (Chambers and MacMahon 1994), allow for biotic movement. Biotically dispersed species tend to increase over time with the establishment of a canopy and favorable habitat conditions attracting birds and other mammal species (Cole et al. 2010; Zahawi et al. 2013; Zahawi and Augspurger 2006). Biotic dispersal is critical for the long-term maintenance and development of plant communities and can account for a large proportion of the total seed dispersal (40-85\%) (Corbin et al. 2016; 
Zahawi and Augspurger 2006). Biotic dispersal has never been tested alongside other assembly mechanisms in this environment.

As plant communities develop, competition and facilitation play a larger role in structuring the community. Competition from the dominant species can negatively impact ecosystem development by limiting the abundance, reproduction of other species, and available nutrients; however, many of these species may also be facilitating species survival by filling a specific niche (Gingras-Hill et al. 2018; MacDougall and Turkington 2005). Long-term effects of competitive non-native and graminoid species on reclamation sites are relatively unknown. It is unknown whether they act as competitors or if they are pioneer species in the early stages of succession (MacDougall and Turkington 2005; Gingras-Hill et al. 2018). These interactions are likely dependent on cover soil as FFMM plant richness is often higher than PMM, leading to increased competition on FFMM (Gingras-Hill et al. 2018). Over time, with an increase in diversity and a decrease in available seedbed competition may become a stronger influence in structuring the plant community.

A better understanding of the mechanisms controlling plant community development on different reclaimed soils will help determine if plant dynamics are following similar trajectories as natural ecosystems. In this study, we use a sequence approach to characterize the change in vegetation community over time on FFMM and PMM by examining the successional processes, i.e., seed bank, seed rain, biotic dispersal, vegetative expansion, and competition (Fig. 1). Figure 1 represents what we expect to occur on the reclamation site. The first step in this process is to describe the patterns that emerge over time and link these to management practices. This study examines three questions: (1) what is the initial plant community on each soil type, (2) how does it change over time, and (3) what plant community assembly mechanisms cause this, including seed bank, seed rain, vegetative expansion, and competition?

\section{Methods}

Study area

The research took place at an oil sands mine approximately $75 \mathrm{~km}$ northwest of Fort McMurray, Alberta, Canada $\left(57.3377^{\circ} \mathrm{N}-111.7552^{\circ} \mathrm{W}\right)$ within the Boreal Mixedwood ecological area (Natural Regions Committee 2006). Upland soils in natural areas are predominantly Gray Luvisols, which have a forest floor layer (LFH) overlaying the mineral soil (Soil Classification Working Group 1998) and are the basis of the FFMM reclamation soil. The vegetation consists of trembling aspen (Populus tremuloides) and white spruce (Picea glauca) mixedwoods (Natural Regions Committee 2006) with understory species including wild rose (Rosa acicularis), bunchberry (Cornus canadensis), and twinflower (Linnaea borealis) (Errington and Pinno 2015). The PMM reclamation soil is derived from organic soils found in peatlands vegetated by black spruce (Picea mariana) with an understory of Labrador tea (Rhododendron groenlandicum), dwarf birch (Betula pumila var. glandulifera), and sedges (Carex sp.) (Beckingham et al. 1996; Soil Classification Working Group 1998). The study location experiences short cool summers and long cold winters, with the average temperature of $17.0{ }^{\circ} \mathrm{C}$ in the warmest month and $-21.9^{\circ} \mathrm{C}$ for the coldest month

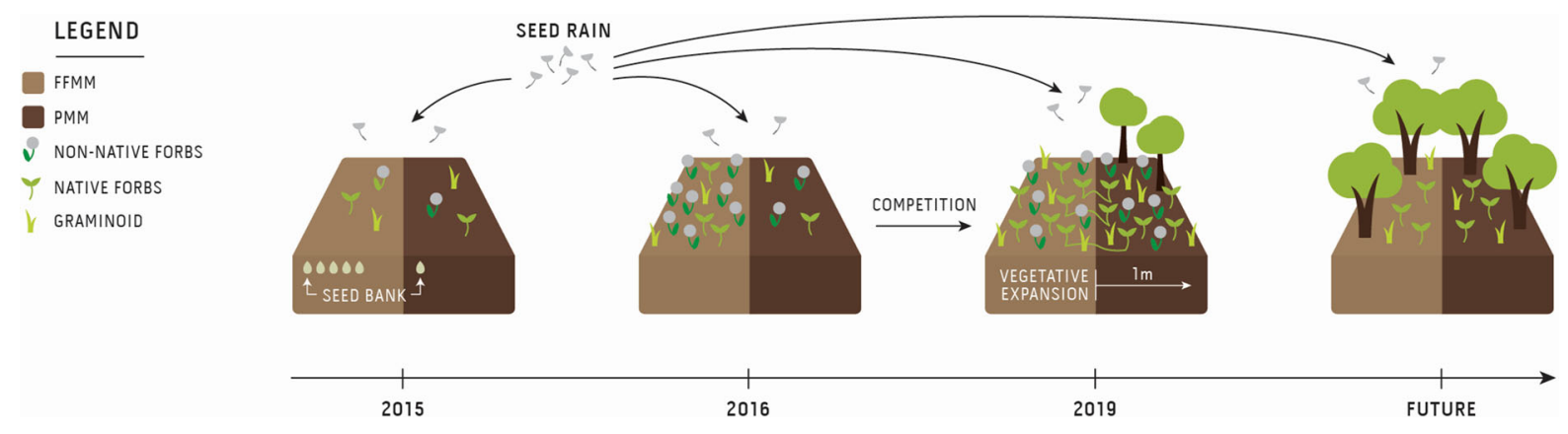

Fig. 1 Conceptual diagram of plant community assembly mechanisms and their influence on reclamation sites over time and soil type 
with an annual precipitation of $418.6 \mathrm{~mm}$ (Government of Canada 2019).

The 19-ha reclamation site was constructed in 2015 (Year 1) on a mine tailings dyke. The site was capped with patches of FFMM surrounded by PMM. The soil characteristics were measured in July of 2019 (Year 5). Volumetric water content and soil temperatures were $6.9 \%$ and $0.8{ }^{\circ} \mathrm{C}$ higher, respectively, in the PMM than FFMM, while $\mathrm{pH}$ was similar between soil types (Table 1). Nutrient supply rates were determined using Plant Root Simulator probes in an aerobic incubation (Western AG Innovations 2019). Macronutrient supply rates of $\mathrm{Ca}^{2+}, \mathrm{Mg}^{2+}, \mathrm{K}^{+}$, and $\mathrm{H}_{2} \mathrm{PO}_{4}{ }^{-}$ were significantly higher on the FFMM, while supply rates of $\mathrm{NO}_{3}-\mathrm{N}$ and $\mathrm{NH}_{4}-\mathrm{N}$ were not significantly different between soil types (Table 1). Spruce seedlings (mainly $P$. glauca with some $P$. mariana) were planted on both soil types with a density of between 1200 and 1600 stems ha $^{-1}$, all other plants established naturally on-site.

Field methods

To characterize the plant community composition throughout the reclamation site, transects were placed across the boundary separating FFMM from the surrounding PMM. Each transect was a total of $25 \mathrm{~m}$ in length, initiating $5 \mathrm{~m}$ inside the FFMM and extending $20 \mathrm{~m}$ perpendicular into the PMM. The transects inside of FFMM only extended to $5 \mathrm{~m}$ because a large portion of the islands were too small for the transect to extend past $5 \mathrm{~m}$. Quadrats of $1-\mathrm{m}^{2}$ were established every meter from 0 to 5 in both the FFMM $(n=5)$ and PMM, as well as at 10, 15, and $20 \mathrm{~m}$ inside PMM $(n=8)$. Ten transects were measured in Year 2, and those 10 transects were re- measured along with an additional 25 transects in Year $5(n=35)$. There were fewer transects at Year 2 as this was considered a preliminary study. At each quadrat, all vascular plants were identified to species level and cover of vascular plants and bare soil (available seed bed) was visually estimated with the lowest cover value of $0.5 \%$. Leaf litter was calculated by (total plant cover - bare soil). Leaf litter was not considered as an available seed bed because the main litter producing species, Calamagrostis canadensis, creates dense mats leading to suboptimal conditions for species to establish (Landhäusser et al. 2007). Species found in the boreal forest have also been found to require reduced cover and vacant seed beds to germinate (Dhar et al. 2018; Hart and Chen 2006). Plant species were separated into functional groups: native forbs, non-native forbs, graminoids (grasses, rushes, and sedges), shrubs, and trees. All graminoids, shrubs, and trees were native. When studying plant expansion, the native forbs were further grouped based on their primary dispersal mechanisms: vegetative, wind, and gravity dispersed (Moss and Packer 1994; Tannas 2001, 2003, 2004). Vegetative species were any species that use asexual reproduction, including rhizomes, stolons, and suckers. Wind-dispersed species were identified based on the adaptation of their seeds, such as wings, pappus, or bristles. Gravitydispersed species did not use vegetative reproduction and had no adaptations on the seed.

Seed bank samples were collected in late May of Year 1 from 28 locations, 14 in each soil type at 0-5 cm and 5-10 cm 5 samples from each depth. Samples were collected in $10 \mathrm{~cm}$ PVC tubes for a pooled sample volume of $2026 \mathrm{~cm}^{3}$. To assess seed rain, seed traps were placed in the spring of Year 1 and collected in the fall of Year 1 at 10 transects. Each seed
Table 1 Soil characteristics for FFMM and PMM

Values are means (standard error) the $p$-values (bold means significant)are the results of generalized mixed-effect models comparing the two soil types

\begin{tabular}{lccr}
\hline & \multicolumn{1}{c}{ FFMM } & \multicolumn{1}{c}{ PMM } & \multicolumn{1}{c}{$p$} \\
\hline Soil pH & $6.7(0.1)$ & $6.6(0.1)$ & 0.850 \\
Volumetric water content $(\%)$ & $17.6(1.1)$ & $24.5(1.1)$ & $<\mathbf{0 . 0 0 1}$ \\
Soil temperature $\left({ }^{\circ} \mathrm{C}\right)$ & $14.3(0.21)$ & $15.1(0.21)$ & $\mathbf{0 . 0 0 5}$ \\
Calcium $\left(\mathrm{Ca}^{2+} \mu \mathrm{g} / 10 \mathrm{~cm}^{2} / 7\right.$ days $)$ & $2165(97)$ & $1857(130)$ & $<\mathbf{0 . 0 0 1}$ \\
Magnesium $\left(\mathrm{Mg}^{2+} \mu \mathrm{g} / 10 \mathrm{~cm}^{2} / 7\right.$ days $)$ & $405(19)$ & $378(15)$ & $<\mathbf{0 . 0 0 1}$ \\
Potassium $\left(\mathrm{K}^{+} \mu \mathrm{g} / 10 \mathrm{~cm}^{2} / 7\right.$ days) & $47(14)$ & $31.3(5.8)$ & $<\mathbf{0 . 0 0 1}$ \\
Phosphate $\left(\mathrm{H}_{2} \mathrm{PO}_{4}{ }^{-} \mu \mathrm{g} / 10 \mathrm{~cm}^{2} / 7\right.$ days $)$ & $1.3(0.1)$ & $0.7(0.1)$ & $<\mathbf{0 . 0 0 1}$ \\
Nitrate $\left(\mathrm{NO}_{3}-\mathrm{N} \mu \mathrm{g} / 10 \mathrm{~cm}^{2} / 7\right.$ days $)$ & $31.5(10.5)$ & $18.7(8.9)$ & 0.430 \\
Ammonium $\left(\mathrm{NH}_{4}-\mathrm{N} \mu \mathrm{g} / 10 \mathrm{~cm}^{2} / 7\right.$ days $)$ & $1.5(0.3)$ & $1.1(0.6)$ & 0.210 \\
\hline
\end{tabular}


trap consisted of a greenhouse flat $(27.79 \mathrm{~cm} \mathrm{~W} \times$ $54.46 \mathrm{~cm} \mathrm{~L} \times 6.20 \mathrm{~cm} \mathrm{D)}$ with a liner of artificial turf at the base of the tray. The seed traps were placed at $0,3,5,10,15$, and $20 \mathrm{~m}$ along transects in both soil types. The seed traps were installed so the top of the tray remained flush with the surrounding ground. Once in the lab, both seed bank and seed rain samples were sieved using a $4 \mathrm{~mm}$ sieve and wet sieved through 500 and $212 \mu \mathrm{m}$ to ensure samples were uniform. Following sieving, greenhouse trays were pre-filled with potting soil and the concentrated samples of seed bank or seed rain were evenly spread into the trays. Control trays were filled with potting soil to determine the potential species coming from the potting mix or aerially through the ventilation system. The control trays were placed throughout the treatment trays to account for approximately $10 \%$ of the area. The trays were placed in the greenhouse and monitored every 2 or 3 days for 4 months. Seedlings were identified to the species level when maturity was reached, counted, and then removed. When no seedling emergence was recorded for more than a week, the samples were mixed and raked to ensure buried seeds or dormant seeds were not prevented from germinating and then re-monitored for another 2 weeks.

\section{Statistical methods}

All data analyses were done using $\mathrm{R}$ software (version R.3.1.1, R Core Team 2019) unless otherwise specified. The plant community data and assembly mechanisms (seed bank, seed rain, and biotic dispersal) data had non-normal distributions based on the ShapiroWilk normality test and residual plots; therefore, nonparametric tests were completed. For analysis of community composition, leaf litter, bare soil, and assembly mechanisms (seed bank, seed rain, and biotic dispersal) a 2-way (functional group cover and richness $\sim$ soil*Year) permutational analysis of variance (permANOVA) (significance level of 0.05) using the ImPerm package (version 2.1.0; Wheeler and Torchiano 2016) with Tukey's HSD Post Hoc test was used. Blocking by transect/plot was not a significant factor for the differences between soil types at either Year 2 or Year 5 for any of the data, therefore was not used in the full analysis.

Community compositions at Year 2 and Year 5 were quantified based on average functional group cover across all transects. When referring to cover this is the average percent cover of plants using each assembly mechanism calculated across all quadrats of the same soil type at each transect (FFMM $n=5$, $\operatorname{PMM} n=8$ ). Proportional cover was calculated based on each functional group within each assembly mechanism divided by the total cover and multiplied by 100 . Seed bank and seed rain were measured by count of seedlings for seedling abundance and species richness for each functional group and were compared between soil types (and depth for seed bank). This allowed us to determine where the plants were originating from initially for both soil types.

In order to distinguish between species arriving onsite via seed bank or seed rain mechanisms, a regional seed rain was calculated, to exclude those species growing from the seed bank and dispersing locally via seed within the first growing season. If species occurred in both the seed bank and seed rain, they were excluded from the regional seed rain community. Species that were not found in either the seed bank or seed rain but still occurred in the aboveground plant community were considered to have arrived via biotic dispersal although it is recognized that some of the species may use other dispersal strategies. These species level classifications of origin (regional seed rain, seed bank, biotic dispersal) were applied to the aboveground plant community composition to explore how the species richness and abundance varied by species origin over time (Year 2, Year 5) and between soil types (FFMM, PMM).

Species expansion from FFMM into PMM was assessed based on mean cover values at each distance in the PMM and the FFMM. This expansion analysis was done for each functional group, native forb dispersal mechanism, and individual species using vegetative dispersal. The expansion was quantified using the randomization test of edge influence (RTEI) comparing the average edge distance values (PMM) to the average reference values (FFMM) using randomizations and blocking by transect (Harper and Macdonald 2001, 2002, 2011). RTEI was based on $\alpha=0.05$ using a two-tailed test and 1000 permutations. Significant values were based on $p<2.5$ being significantly less than the reference, and $p>97.5$ being significantly higher than the FFMM. For further information on RTEI see Harper and Macdonald (2001, 2002, 2011).

Pearson's correlation was used to compare the cover of various functional groups to one another 
(native forbs to non-native forbs, non-native forbs to graminoids, and native forbs to graminoids) in Year 2, Year 5, and on both soil types. Negative correlations are interpreted to indicate competition, while positive correlations indicate facilitation or no direct interaction.

\section{Results}

Over 5 years, there has been an increase in total vegetation cover and richness in both soil types (Fig. 2f) despite different starting conditions. Species richness was initially higher on FFMM, but by Year 5 was higher on PMM (FFMM Year 2 species richness $=74$, Year 5 species richness $=80 ;$ PMM Year 2 species richness $=61$, Year 5 species richness $=86$ ). Total cover in Year 2 was higher on FFMM compared to $\mathrm{PMM}$ (FFMM $=27.6 \%$; $\mathrm{PMM}=3.8 \% ; p<0.001$ ) (Fig. 2f). Cover increased differentially between soil types but total cover was still slightly higher on FFMM in Year $5 \quad(\mathrm{FFMM}=43.4 \% ; \quad \mathrm{PMM}=39.7 \%$; $p=0.005$ ) (Fig. 2f). Bare soil percent cover (available seed bed) differed by year and soil type. In Year 2, percent cover of bare soil on FFMM was $72.4 \%$, and on PMM 95.9\% $(p<0.001)$, but by Year 5 was reduced to $5 \%$ on FFMM and $20.8 \%$ on PMM $(p<0.001)$. Leaf litter in Year 2 had cover of $<1 \%$ $(p=1)$ in both soil types. By Year 5 leaf litter was $51.6 \%$ on the FFMM and $39.6 \%$ on PMM $(p<0.001)$.

Beyond total plant cover, there were different temporal responses by functional groups. In Year 2, the majority of the cover was from non-native forbs on FFMM $($ FFMM cover $=20.9 \%$; $\mathrm{PMM}$ cover $=1.4 \%$; $p<0.001$ ) (Fig. 2b). However, by Year 5 non-native forbs on FFMM had $7.9 \%$ cover and $7.7 \%$ cover on PMM ( $p=0.999$ ) (Fig. 2b). Initially native forbs accounted for $<5 \%$ cover on both soil types $(p>0.05)$ but increased by Year 5 to $24 \%$ on FFMM and to $19.5 \%$ on PMM $(p<0.001)$ (Fig. 2a). Graminoid cover in Year 2 was similar between soil types $(\mathrm{FFMM}=2.0 \%, \quad \mathrm{PMM}=0.3 \%, \quad p=0.320)$; however, by Year 5 there was a differential increase in cover by soil resulting in a higher graminoid cover on FFMM (9.9\%) than PMM $(5.9 \%)(p<0.001)$ (Fig. 2c). Shrub cover was minimal in Year 2 with no difference between soil types ( $p=0.999)$ (Fig. 2d). In Year 5, shrub cover remained similar on FFMM was
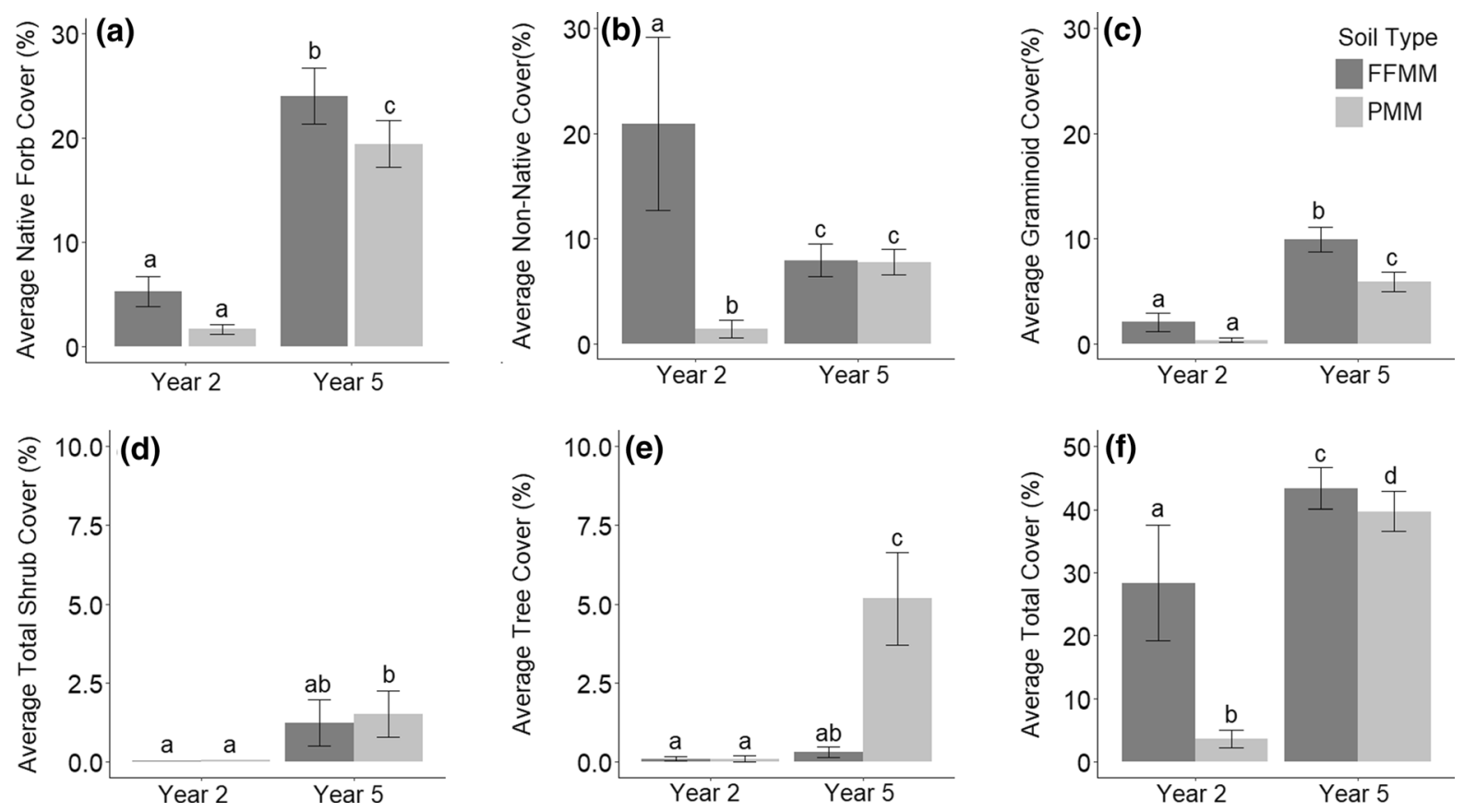

Fig. 2 Functional group (a native forb, b non-native forb, c graminoid, d total shrub, e tree) and total cover (f) with change over time from Year 2 to Year 5 in FFMM and PMM. Letters

indicate significant differences (significance level of 0.05) based on permANOVA results showing the interaction over time and between soil types. Values are means with standard error bars 
$1.2 \%(p=0.200)$ and on PMM there was an increase to $1.4 \%$ cover ( $p=0.014$ ) (Fig. $2 \mathrm{~d}$ ). Non-planted tree cover was minimal in Year 2 at $<0.1 \%$ and by Year 5 increased on PMM to $5.2 \%(p<0.001)$ but only to $0.3 \%$ on FFMM ( $p=0.999$ ) (Fig. 2e).

Seedbank germination resulted in a total emergence of 2135 seedlings representing 55 species (FFMM species richness $=51$, PMM species richness $=29$ ). More seedlings emerged from FFMM compared to PMM $\quad(\mathrm{FFMM}=86.3 \%, \quad \mathrm{PMM}=13.7 \%$ of total seedlings, $p<0.001)$. By functional group, there was higher seedling emergence in all groups in the FFMM compared to PMM ( $p<0.001)$.

Species originating from the seed bank were the largest contributor to the aboveground community in both Year 2 and Year 5. Initially in the aboveground plant community, species originating from the seed bank accounted for $25.9 \%$ cover on FFMM (species richness $=34,93.6 \%$ of proportional cover) and $2.8 \%$ of cover on PMM (species richness $=30,73.9 \%$ of proportional cover) $(p<0.001)$ (Table 2$)$. The aboveground community originating from the seed bank in Year 2 consisted mainly of non-native forbs which had a cover of $21.9 \%$ on FFMM (79.2\% of proportional cover) and $1.6 \%$ on PMM (42.9\% of proportional cover) $(p<0.001)$ (Table 2). By Year 5, cover of species originating from the seed bank remained similar on FFMM at $25.7 \%$ (species richness $=34$, $59 \%$ of proportional cover) ( $p=0.663)$ and increased to $17.2 \%$ on PMM (species richness $=35,43.3 \%$ of proportional cover) $(p<0.001)$ (Table 2). Between Year 2 and Year 5, there was a change in composition of the species originating from the seed bank shifting from dominance by non-native forbs to native forbs and graminoids.

Seed rain samples had a total emergence of 32,811 individual seedlings from all samples representing 68 species (FFMM species richness $=62$, PMM species richness $=50)$. Total seedling emergence was similar between soil types $(\mathrm{FFMM}=49 \%, \mathrm{PMM}=51 \%$ of

Table 2 Cover $(\%)$ of each functional group (native forbs, graminoids, non-native forbs, shrubs, and trees) originating from the assembly mechanism (seed bank, seed rain, and biotic dispersal)

\begin{tabular}{|c|c|c|c|c|c|c|c|c|}
\hline & \multicolumn{4}{|l|}{ Cover $(\%)$} & \multicolumn{4}{|c|}{ Proportion of cover $(\%)$} \\
\hline & \multicolumn{2}{|l|}{ Year 2} & \multicolumn{2}{|l|}{ Year 5} & \multicolumn{2}{|l|}{ Year 2} & \multicolumn{2}{|l|}{ Year 5} \\
\hline & FFMM & PMM & FFMM & PMM & FFMM & PMM & FFMM & PMM \\
\hline \multicolumn{9}{|l|}{ Native forbs } \\
\hline Seed bank & $2.8(0.7)$ & $0.9(0.2)$ & $10.1(1.5)$ & $5.8(1.1)$ & 10.2 & 23.2 & 23.2 & 14.7 \\
\hline Seed rain & $1.1(0.4)$ & $0.5(0.1)$ & $8.7(1.8)$ & $7.1(1.1)$ & 4.0 & 13.6 & 20 & 17.8 \\
\hline Biotic dispersal & $<0.5$ & $<0.5$ & $5.3(1.1)$ & $6.7(1.4)$ & $<1$ & 7.5 & 12 & 16.9 \\
\hline \multicolumn{9}{|l|}{ Graminoid } \\
\hline Seed bank & $1.1(0.5)$ & $<0.5$ & $8.5(1.0)$ & $4.8(0.4)$ & 4.1 & 8.0 & 19.4 & 12.2 \\
\hline Seed rain & $<0.5$ & $<0.5$ & $<0.5$ & $0.5(0.1)$ & $<1$ & $<1$ & $<1$ & 1.1 \\
\hline Biotic dispersal & $0.3(0.2)$ & $<0.5$ & $1.1(0.1)$ & $0.5(0.1)$ & 1.3 & $<1$ & 2.4 & 1.4 \\
\hline \multicolumn{9}{|l|}{ Non-native forbs } \\
\hline Seed bank & $21.9(6.5)$ & $1.6(0.1)$ & $7.1(1.0)$ & $6.5(0.6)$ & 79.2 & 42.8 & 16.4 & 16.5 \\
\hline Seed rain & $<0.5$ & 0 & $0.4(0.1)$ & $0.8(0.3)$ & $<1$ & 0 & $<1$ & 2.1 \\
\hline Biotic dispersal & $<0.5$ & $<0.5$ & $0.6(0.1)$ & $<0.5$ & $<1$ & $<1$ & 1.3 & $<1$ \\
\hline \multicolumn{9}{|l|}{ Shrubs } \\
\hline Seed rain & 0 & 0 & $0.9(0.4)$ & $1.5(0.3)$ & $<1$ & $<1$ & 2.1 & 3.7 \\
\hline Biotic dispersal & 0 & $<0.5$ & $<0.5$ & $<0.5$ & 0 & $<1$ & $<1$ & $<1$ \\
\hline \multicolumn{9}{|l|}{ Tree } \\
\hline Seed rain & $<0.5$ & $<0.5$ & $<0.5$ & $5.1(0.8)$ & $<1$ & 2.7 & $<1$ & 13 \\
\hline
\end{tabular}

Values are averages (standard error) for each soil type and year. Proportion of cover (\%) are separated by year and soil type for each assembly mechanism 
total seedlings, $p=1$ ). Based on all seedlings emerged, $62.3 \%$ used wind-dispersal.

Species originating from the seed rain form the second largest contribution to the aboveground plant community, behind that of the seed bank species. In Year 2, species originating from the seed rain account for a cover $<2 \%$ on both soil types $(p=0.991)$, however, they account for $4.5 \%$ and $16.8 \%$ of proportional cover on FFMM (species richness = 10) and PMM (species richness $=8$ ), respectively (Table 2). By Year 5, there was an increase in species richness to 17 and 14 on FFMM and PMM.

Biotically dispersed species in the aboveground plant community account for $<0.5 \%$ of cover on both soil types (FFMM species richness $=11$; PMM species richness $=13 ; p=0.999$ ) in Year 2 (Table 2). In Year 5, there is an increase of cover originating from biotic dispersal in both soil types to $7.2 \%$ and $7.5 \%$ on FFMM and PMM (FFMM species richness $=32$, proportional cover $=16.5 \%$; PMM species richness $=33$ species, proportional cover $=19 \%$; $p<0.001$ ) (Table 2). The shift in the community originating from biotic dispersal is mainly due to native forbs $(p=0.001)$; other functional groups had a cover $<0.89 \%$ which is $<2 \%$ of proportional cover on both soil types $(p>0.256)$ (Table 2 ).

While the overall cover is different between soil types, there appears to be no movement of species from FFMM into PMM for graminoids (RTEI $p=0.1$ ) or non-native forbs (RTEI $p>2.8$ ). Native forbs with vegetative reproduction, however, had an average dispersal from FFMM into PMM of $1 \mathrm{~m}$, although this varied for individual species. For example, Fragaria

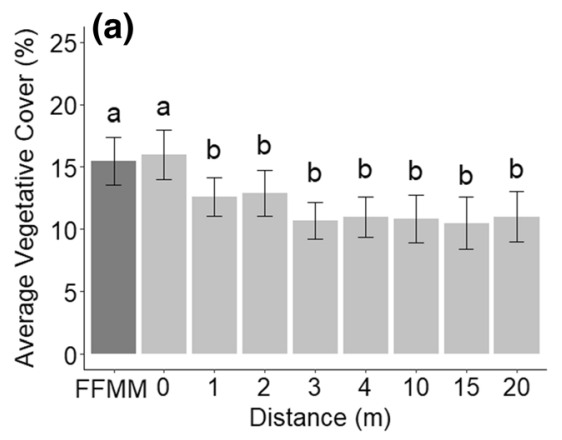

Fig. 3 The average percentage of each native forb dispersal mechanism: a native forb vegetative, b Fragaria virginiana at $0-4,10,15$, and $20 \mathrm{~m}$ distances in the PMM ( $n=35$ transects $)$ virginiana expanded out to $2 \mathrm{~m}$ from the FFMM into the PMM (Fig. 3).

The plant community on FFMM showed no significant correlations between any of the functional group cover $(\%)$ comparisons in either year $(p>0.05)$ indicating neither competition nor facilitation. By comparison, in Year 2 on PMM, all functional group comparisons showed a positive correlation $(p<0.011)$. In Year 5 on PMM, only native forbs and non-native forb cover continued to be positively correlated ( $p=0.015)$, but there were no relationships among other functional groups.

\section{Discussion}

This study demonstrates that the seed bank initially is the main driver in the plant community with greater cover and diversity on FFMM compared to PMM. Over time, multiple drivers shift the plant community resulting in convergence of the plant community between soil types by Year 5. The initial plant communities are distinct on both soil types, FFMM being dominated by early successional non-native communities originating from the seed bank whereas PMM had very low plant cover. Five years after material placement, plant communities are comparable in species composition and consist of predominantly native species on both soil types. The seed bank is still the largest contributor to the plant community on both soil types due to delayed germination, slow growth rates of native species, and local seed rain from seed bank species (Renault et al. 2000). Seed rain and biotic dispersal are the next largest contributors with

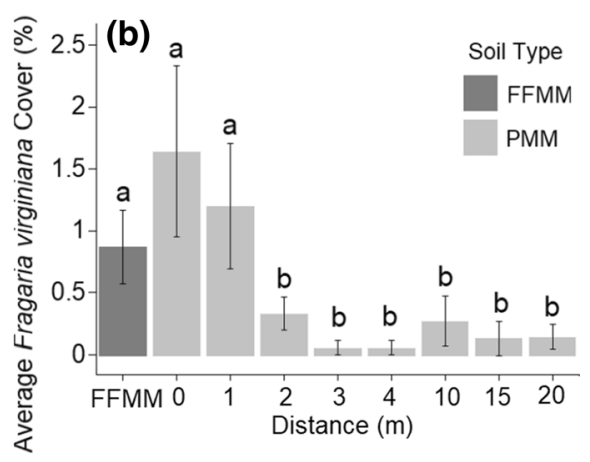

from the FFMM (average of 5 plots per 35 transects). Bars represent standard error and letters indicate significant differences based on RTEI results 
the addition of trees and other late-successional species. Plant expansion from FFMM into surrounding PMM occurs at a slow some native forbs moving up to $2 \mathrm{~m}$ after 5 years. Competition is not a large contributor in structuring the community at this early stage, likely because there are still adequate available seedbeds and resources.

The seed bank plays a critical role in the aboveground vegetation community on both soil types. However, the FFMM seed bank had $5 \times$ more seed and $2 \times$ higher diversity compared to PMM. The initial vegetation community reflected the seed bank by having $10 \times$ higher cover and $2 \times$ higher diversity on the FFMM. Initially, non-native forbs originating from the seed bank were the largest contributor to the aboveground community. Non-native species are highly adaptable and have rapid expansion (MacDougall and Turkington 2005); thus, they dominate the initial plant community, accounting for $>75 \%$ total proportional plant cover. Non-native forbs are generally found at low amounts within natural forest seed banks (Buss et al. 2020; Bellairs and Bell 1993; Jauni et al. 2015). Therefore, the non-native forbs in the seed bank likely originated after the donor site was cleared or from contamination during salvage and placement operations (Knapp et al. 2016; Moore 1980). By Year 5 there was a shift to native forb species, originating from the seed bank as the largest contributor to the aboveground community on both soil types. This increase over time is likely due to the continuous establishment by seed (e.g., Potentilla norvegica, Plantago major, and Rubus idaeus) and growth of individual perennial plants. A portion of the species within the seed bank can also have an extended dormancy, which could lead to the delayed establishment (e.g., Betula papyrifera, Cornus canadensis, and Mentha arvensis) (Greene et al. 1999; Tappeiner and Alaback 1989).

Seed rain was similar across both soil types and the majority of species found within the seed traps were wind-dispersed early successional species. Over time there is a continual addition of these wind-dispersed species, which was seen through the increase of cover and richness from seed rain originating species in the aboveground community on both soil types. With more time, an increase in vegetative barriers and a decrease of available microsites may lower the potential for seed rain originating species to establish (Hart and Chen 2006). Colonization rates on disturbed sites can be strongly influenced by remnant patches that are in close proximity and in some instances colonization relies entirely on species found in those patches (Bochet et al. 2007; Mola et al. 2011).

In addition to herbaceous species, the vast majority of trees (mainly Populus tremuloides and Populus balsamifera) and Salix species established from seed rain and occurred mainly on PMM. Stefani et al. (2018) found in a nearby reclamation site that Populus tremuloides were colonizing on reclaimed sites via seed recruitment rather than clonal propagation from root suckers based on the high rate of genetic diversity between individual trees on these sites. Tree species, such as Populus tremuloides, are prolific seed producers with small wind-dispersed seeds requiring adequate soil moisture during germination and early seedling development (Landhäusser et al. 2019). PMM creates ideal conditions for tree establishment due to higher water holding capacity, organic matter, surface roughness, and reduced competition (Pinno and Errington 2015). These conditions create beneficial microclimatic effects such as reduced temperature and evaporation and increasing trapped seeds (Bradshaw 2000).

A variety of species were found on-site that did not originate from either the seed bank or seed rain, with many of these species requiring biotic dispersal (Matlack 1994). Recruitment of biotic-dispersed species was higher on PMM likely due to the increased tree and shrub canopy attracting animals that might disperse seed (Cole et al. 2010; Zahawi and Augspurger 2006; Zahawi et al. 2013). Our study found a combination of late-successional fruit-bearing woody species (Ribes sp., Shepherdia canadensis, and Arctostaphylos uva-ursi), native forb species (Trifolium pratense, Rubus pubescens, and Galium triflorum), and graminoids (Leymus innovatus and Elymus canadensis) likely establishing through biotic dispersal by year 5 .

The proximity to the remnant forest will affect the ability of seed-dispersing animals and wind dispersing plant species to move through the landscape (DeClerck et al. 2010). The reclamation site in our study is located near a river with remnant forests on two sides, likely leading to a continual dispersal of late-successional species. In contrast, Jones and Landhäusser (2018) found limited evidence of biotic dispersal on a similarly aged oil sands reclamation site, though their site was isolated in the center of a 
large mine with no intact forest for several kilometers, which may have limited availability for biotic dispersal. By comparing both studies that are similar in age and soil configuration technique, we can see the importance of distance to remnant forests when using a passive reclamation technique to increase the ability of biotic movement and seed rain through the reclamation site.

Overall, there was a slow rate of expansion from the species-rich FFMM into the surrounding PMM. Native forbs generally expanded at a slow rate into the PMM with the average dispersal up to $2 \mathrm{~m}$ after 5 years. Jones and Landhäusser (2018) found similar rates of vegetative expansion from FFMM into PMM from an average of $<2 \mathrm{~m}$ to a maximum of $4 \mathrm{~m}$. The main species showing vegetative expansion used stolons (e.g. Fragaria virginiana). Individual plants of $F$. virginiana may produce one to four stolons a season and non-branching stolons will root when in contact with moist substrate up to $1 \mathrm{~m}$ from the parent plant (Angevine 1983). However, expansion is slow because stolons decay by late summer, losing the connections between nodes (Angevine 1983). The slow rate of expansion via vegetative dispersal has been identified as one of the limitations of using patches in reclamation (Robinson and Handel 2000).

Currently, there is little evidence of competition among functional groups, likely due to the availability of growing space and resources, thereby limiting competition. On FFMM none of the functional groups had a negative interaction indicating that there was no competition occurring. However, competition will likely play a larger role in structuring the vegetation community in the future once all available growing space is occupied. The initial spike of non-native species on FFMM indicates a combination of species exploiting initial resources (Alday et al. 2011; Buss et al. 2018; Gingras-Hill et al. 2018) and the higher amounts of seeds present within the seedbank in the FFMM (Errington and Pinno 2015; Mackenzie and Naeth 2010). Over time on the FFMM the species cover remained relatively constant but continued to increase on PMM, this is related to the available growing space (bare soil). At Year 5 on FFMM, there was $5 \%$ available growing space compared to PMM where there was $20 \%$ available growing space present providing more area for continual increase of cover over time.

\section{Conclusion}

This study provides new insights into the general pathways of succession on various soil types after a large scale anthropogenic disturbance. The seed bank is one of the most important assembly mechanisms in developing the aboveground plant community; therefore, soil salvage and placement methods reducing the degradation of the seed bank are critical. Our results indicate that seed rain and biotic dispersal are also large contributors to the aboveground community. The effect of the surrounding environment was no apart of this study; however, the proximity to remnant forest seems to be valuable in establishing higher biodiversity, trees, and late-successional woody species by increasing the ability of wind-dispersed seeds or seeddispersing animals to arrive on the landscape. Techniques such as placing coarse woody debris or bird nesting sites on reclamation areas will also increase habitat and the potential arrival of late-successional biotic-dispersed species. Competition from graminoids and non-native forbs did not seem to have an effect in structuring the vegetation community or alter the successional trajectory. The results of this study highlight the importance of multiple assembly mechanisms in developing a diverse self-sustaining ecosystem.

Acknowledgements We thank Brea Burton, Sofia Toledo, Mathew Anderson, and Edith Li for the field and lab work.

Author contributions All authors contributed to the study conception and design. In 2015 and 2016, material preparation and data collection were performed by RCE and BDP. In 2019, material preparation and data collection were performed by KET. All data were analyzed by KET. The first draft of the manuscript was written by KET and all authors commented on previous versions of the manuscript. All authors read and approved the final manuscript.

Funding This study was funded by Canadian Natural Resources Limited and by Alberta Conservation Association.

Data availability All data are available from the authors upon request.

\section{Compliance with ethical standards}

Conflict of interest The authors declare there is no conflict of interest.

Ethical approval Not applicable. 
Consent to participate The authors all consent to participate in the publishing of this manuscript.

Consent for publication The authors all consent to publish this manuscript.

Open Access This article is licensed under a Creative Commons Attribution 4.0 International License, which permits use, sharing, adaptation, distribution and reproduction in any medium or format, as long as you give appropriate credit to the original author(s) and the source, provide a link to the Creative Commons licence, and indicate if changes were made. The images or other third party material in this article are included in the article's Creative Commons licence, unless indicated otherwise in a credit line to the material. If material is not included in the article's Creative Commons licence and your intended use is not permitted by statutory regulation or exceeds the permitted use, you will need to obtain permission directly from the copyright holder. To view a copy of this licence, visit http://creativecommons.org/licenses/by/4.0/.

\section{References}

Alday JG, Pallavicini Y, Marrs RH, Martínez-Ruiz C (2011) Functional groups and dispersal strategies as guides for predicting vegetation dynamics on reclaimed mines. Plant Ecol 212:1759-1775. https://doi.org/10.1007/s11258-0119947-6

Alberta Environment and Water (2012) Best management practices for conservation of reclamation materials in the mineable oil sands region of Alberta, Direct. 1-161. https://doi.org/978-1-4601-0048-6

Angevine MW (1983) Variations in the demography of natural populations of the wild strawberries Fragaria vesca and $F$. virginiana. J Ecol 71:959. https://doi.org/10.2307/2259605

Beckingham JD, Corns IGW, Archibald JH (1996) Field guide to ecosites of west-central Alberta. Vancouver, British Columbia

Bellairs SM, Bell DT (1993) Seed stores for reclamation of species-rich shrubland vegetation following mining in Western Australia. Restor Ecol 1:231-240

Bochet E, García-fayos P, Tormo J (2007) Road slope revegetation in semiarid Mediterranean environments. Part I: Seed dispersal and spontaneous colonization. Restor Ecol 15:88-96. https://doi.org/10.1111/j.1526-100X.2006. 00193.x

Bradshaw A (2000) The use of natural processes in reclamation-advantages and difficulties. Landsc Urban Plan 51:89-100. https://doi.org/10.1016/S01692046(00)00099-2

Brandt JP, Flannigan MD, Maynard DG, Thompson ID, Volney WJA (2013) An introduction to Canada's boreal zone: ecosystem processes, health, sustainability, and environmental issues. Environ Rev 21:207-226. https://doi.org/10. 1139/er-2013-0040

Buss J, Stratechuk K, Pinno BD (2018) Growth and competition among understory plants varies with reclamation soil and fertilization. Ecol Process 7:1-8. https://doi.org/10.1186/ s13717-018-0123-y
Buss J, Pinno BD, Quideau S (2020) A comparison between reclamation stockpiles and boreal forest seed banks and plant communities. https://doi.org/10.1111/rec.13196

Chambers JC, MacMahon JA (1994) A day in the life of a seed: movements and fates of seeds and their implications for natural and managed systems. Annu Rev Ecol Syst 25:263-292. https://doi.org/10.1146/annurev.es.25. 110194.001403

Cole RJ, Holl KD, Zahawi RA (2010) Seed rain under tree islands planted to restore degraded lands in a tropical agricultural landscape. Ecological Applications 20(5):1255-1269

Cook WM, Yao J, Foster BL, Holt RD, Patrick LB (2005) Secondary succession in an experimentally fragmented landscape: community patterns across space and time. Ecology 86:1267-1279. https://doi.org/10.1890/04-0320

Corbin JD, Robinson GR, Hafkemeyer LM, Handel SN (2016) A long-term evaluation of applied nucleation as a strategy to facilitate forest reclamation. Ecol Appl 26:104-114. https://doi.org/10.1890/15-0075.1/suppinfo

DeClerck FAJ, Chazdon R, Holl KD, Milder JC, Finegan B, Martinez-Salinas A, Imbach P, Canet L, Ramos Z (2010) Biodiversity conservation in human-modified landscapes of Mesoamerica: past, present and future. Biol Conserv 143:2301-2313. https://doi.org/10.1016/j.biocon.2010.03. 026

Dhar A, Comeau PG, Vassov R (2018) Effects of cover soil stockpiling on plant community development following reclamation of oil sands sites in Alberta. Restor Ecol. https://doi.org/10.1111/rec.12858

Errington RC, Pinno BD (2015) Early successional plant community dynamics on a reclaimed oil sands mine in comparison with natural boreal forest communities. Ecoscience 22:133-144. https://doi.org/10.1080/11956860.2016. 1169385

Gallagher FJ, Pechmann I, HolZafel C, Grabosky J (2011) Altered vegetative assemblage trajectories within an urban brownfield. Environ Pollut 159:1159-1166. https://doi.org/ 10.1016/j.envpol.2011.02.007

Gingras-Hill T, Nwaishi FC, Macrae ML, Price JS, Petrone RM (2018) Ecohydrological functioning of an upland undergoing reclamation on post-mining landscape of the Athabasca oil sands region, Canada. Ecohydrology 11:1-12. https://doi.org/10.1002/eco.1941

Government of Canada (2019) Canadian Climate Normals 1981-2010 Station Data. https://climate.weather.gc.ca/ climate_normals/results_1981_2010_e.html?searchType= stnProv\&lstProvince $=$ AB\&txtCentralLatMin $=$ $0 \&$ txtCentralLatSec $=0 \&$ txtCentralLongMin= $0 \&$ txtCentralLongSec $=0 \& \operatorname{stnID}=2704 \&$ dispBack $=0$. Accessed 22 Apr 2020

Greene DF, Zasada JC, Sirois L, Kneeshaw D, Morin H, Charron I, Simard M-J (1999) A review of the regeneration dynamics of North American boreal forest tree species. Can J For Res 29:824-839. https://doi.org/10.1139/cjfr-296-824

Harper KA, Macdonald SE (2001) Structure and composition of riparian boreal forest: new methods for analyzing edge influence. Ecology 82:649-659. https://doi.org/10.1890/ 0012-9658(2001)082[0649:SACORB]2.0.CO;2 
Harper KA, Macdonald SE (2002) The critical values program for assessing edge influence. ESA 83:61-62

Harper KA, Macdonald SE (2011) Quantifying distance of edge influence: a comparison of methods and a new randomization method. Ecosphere 2:1-17. https://doi.org/10.1890/ es11-00146.1

Hart SA, Chen HYH (2006) Understory vegetation dynamics of North American boreal forests. CRC Crit Rev Plant Sci 25:381-397. https://doi.org/10.1080/07352680600819286

Hobbs RJ, Higgs E, Hall CM, Bridgewater P, Chapin FS III, Ellis EC et al (2014) Managing the whole landscape: historical, hybrid, and novel ecosystems. Front Ecol Environ 12:557-564. https://doi.org/10.1890/130300

Jauni M, Gripenberg S, Ramula S (2015) Non-native plant species benefit from disturbance: a meta-analysis. Oikos 124:122-129

Jones CE, Landhäusser SM (2018) Plant recolonization of reclamation areas from patches of salvaged forest floor material. Appl Veg Sci 21:94-103. https://doi.org/10.1111/ avsc. 12350

Knapp S, Stadler J, Harpke A, Klotz S (2016) Dispersal traits as indicators of vegetation dynamics in long-term old-field succession. Ecol Indic 65:44-54. https://doi.org/10.1016/j. ecolind.2015.10.003

Landhäusser SM, Mulak TL, Lieffers VJ (2007) The effect of roots and litter of Calamagrostis canadensis on root sucker regeneration of Populus tremuloides. Forestry 80:481-488. https://doi.org/10.1093/forestry/cpm035

Landhäusser SM, Pinno BD, Mock KE (2019) Tamm review: Seedling-based ecology, management, and restoration in aspen (Populus tremuloides). For Ecol Manag 432:231-245. https://doi.org/10.1016/j.foreco.2018.09. 024

Macdonald SE, Fenniak TE (2007) Understory plant communities of boreal mixedwood forests in western Canada: natural patterns and response to variable-retention harvesting. For Ecol Manag 242:34-48. https://doi.org/10. 1016/j.foreco.2007.01.029

Macdonald SE, Quideau S, Landhäusser SM (2012) Rebuilding boreal forest ecosystems after industrial disturbance. Restor Reclam Boreal Ecosyst. https://doi.org/10.1017/ CBO9781139059152.010

Macdonald SE, Landhäusser SM, Skousen J, Franklin J, Frouz J, Hall S, Jacobs DF, Quideau S (2015) Forest reclamation following surface mining disturbance: challenges and solutions. New For 46:703-732. https://doi.org/10.1007/ s11056-015-9506-4

MacDougall AS, Turkington R (2005) Are invasive species the drivers or passengers of change in degraded ecosystems? Ecology 86:42-55. https://doi.org/10.1890/04-0669

Mackenzie DD, Naeth MA (2010) The role of the forest soil propagule bank in assisted natural recovery after oil sands mining. Restor Ecol 18:418-427. https://doi.org/10.1111/j. 1526-100X.2008.00500.x

Mackenzie MD, Quideau SA (2012) Laboratory-based nitrogen mineralization and biogeochemistry of two soils used in oil sands reclamation. Can J Soil Sci 92:131-142. https://doi. org/10.4141/CJSS2010-070

Matlack GR (1994) Plant species migration in a mixed-history forest landscape in Eastern North America. Am J Bot 75:1491-1502
McMillan R, Quideau SA, MacKenzie MD, Biryukova O (2007) Nitrogen mineralization and microbial activity in oil sands reclaimed boreal forest soils. $\mathrm{J}$ Environ Qual 36:1470-1478. https://doi.org/10.2134/jeq2006.0530

Mola I, Jiménez MD, López-Jiménez N, Casado MA, Balaguer L (2011) Roadside reclamation outside the revegetation season: management options under schedule pressure. Restor Ecol 19:83-92. https://doi.org/10.1111/j.1526100X.2009.00547.x

Moore PD (1980) Soil seed banks. Nature 284:123-124

Moss EH, Packer J (1994) Flora of Alberta, 2nd edn. University of Toronto Press, Toronto

Natural Regions Committee (2006) Natural regions and subregions of Alberta. Government of Alberta. https://www.cd. gov.ab.ca/preserving/parks/anhic/Natural_region_report. asp. Accessed 20 Sept 2018

Pinno BD, Errington RC (2015) Maximizing natural trembling aspen seedling establishment on a reclaimed boreal oil sands site. Ecol Restor 33:43-50. https://doi.org/10.3368/ er.33.1.43

Pinno BD, Hawkes VC (2015) Temporal trends of ecosystem development on different site types in reclaimed boreal forests. Forests 6:2109-2124. https://doi.org/10.3390/ f6062109

R Core Team (2019) R: a language and environment for statistical computing. R foundation for statistical computing, Vienna, Austria. ISBN 3-900051-07-0. https://www.Rproject.org/. Accessed 13 Sept 2019

Rey Benayas JM, Bullock JM, Newton AC (2008) Creating woodland islets to reconcile ecological reclamation, conservation, and agricultural land use. Front Ecol Environ 6:329-336. https://doi.org/10.1890/070057

Renault S, Zwiazek JJ, Fung M, Tuttle S (2000) Germination, growth and gas exchange of selected boreal forest seedlings in soil containing oil sands tailings. Environ Pollut 107:357-365. https://doi.org/10.1016/S02697491(99)00167-0

Roberts MR (2004) Response of the herbaceous layer to natural disturbance in North American forests. Can J Bot 82:1273-1283. https://doi.org/10.1139/b04-091

Robinson GR, Handel SN (2000) Directing spatial patterns of recruitment during an experimental urban woodland reclamation. Ecol Appl 10:174. https://doi.org/10.2307/ 2640994

Rydgren K, Hestmark G, Okland RH (1998) Revegetation following experimental disturbance in a boreal old-growth Picea abies forest. J Veg Sci 9:763-776. https://doi.org/10. $2307 / 3237042$

Silvertown J (2008) The evolutionary maintenance of sexual reproduction: evidence from the ecological distribution of asexual reproduction in clonal plants. Int $\mathrm{J}$ Plant Sci 169:157-168. https://doi.org/10.1086/523357

Soil Classification Working Group (1998) The Canadian system of soil classification, 3rd edn. Agriculture and Agri-Food Canada Publication, Ottawa

Stefani F, Isabel N, Morency MJ, Lamothe M, Nadeau S, Lachance D, Li EHY, Greer C, Yergeau É, Pinno BD, Séguin A (2018) The impact of reconstructed soils following oil sands exploitation on aspen and its associated belowground microbiome. Sci Rep 8:1-13. https://doi.org/ 10.1038/s41598-018-20783-6 
Tannas KE (2001) Common plants of the western rangelands, vol 1. Grasses and grass-like species, 1st edn. Alberta Agriculture, Food and Rural Development, Lethbridge

Tannas KE (2003) Common plants of the western rangelands, vol 2. Trees and shrubs, 1st edn. Alberta Agriculture, Food and Rural Development, Lethbridge

Tannas KE (2004) Common plants of the western rangelands, vol 3. Forbs, 1st edn. Alberta Agriculture, Food and Rural Development, Lethbridge

Tappeiner JC, Alaback PB (1989) Early establishment and vegetative growth of understory species in the western hemlock-Sitka spruce forests of southeast Alaska. Can J Bot 67:318-326. https://doi.org/10.1139/b89-046

Western Ag (2019) PRS technology analysis. https://www. westernag.ca/innovations/technology/analysis_units. Accessed 14 Febr 2019

Wheeler B, Torchiano M (2016) lmPerm: permutation tests for linear models. https://CRAN.R-project.org/package= lmPerm. Accessed 13 Sept 2019
Young TP, Chase JM, Huddleston RT (2001) Community succession and assembly: comparing, contrasting and combining paradigms in the context of ecological reclamation. Ecol Restor 19:5-18. https://doi.org/10.3368/er.19.1.5

Zahawi RA, Augspurger CK (2006) Tropical forest reclamation: tree islands as recruitment foci in degraded lands of Honduras. Ecol Appl 16:464-478. https://doi.org/10.1890/ 1051-0761(2006)016[0464:TFRTIA]2.0.CO;2

Zahawi RA, Holl KD, Cole RJ, Reid JL (2013) Testing applied nucleation as a strategy to facilitate tropical forest recovery. J Appl Ecol 50:88-96. https://doi.org/10.1111/13652664.12014

Publisher's Note Springer Nature remains neutral with regard to jurisdictional claims in published maps and institutional affiliations. 